\section{Prediction of Moisture Changes in Roasted and Seasoned Lavers, Porphyra yezoensis, Double-packaged with Polyolefin Plastic Materials}

\author{
Takashi Hirata*, Naoya Watanabe** \\ and Takasuke IsHITANI* \\ * National Food Research Institute, Ministry of \\ Agriculture, Forestry and Fisheries, \\ 1-2 Kannondai-2, Yatabe-machi, \\ Tsukuba-gun, Ibaraki 305 \\ ** Knorr Food Co., Ltd., 976, Shimonoge, \\ Takatsu-ku, Kawasaki-shi, Kanagawa 213
}

\begin{abstract}
A method of prediction of changes in moisture content of seasoned and roasted lavers in doublepackaging systems was investigated by two steps. In the first step, the moisture sorption isotherms of roasted and seasoned lavers were determined. An empirical equation proved to be suitable to express the isotherms of the both products. In the second step, a generalized mathematical model together with the empirical equation of the isotherms was used to predict the moisture changes in roasted and seasoned lavers double-packaged with polyolefin materials. The model was adequa tely feasible to predict the moisture changes since the predicted values agreed fairly well with the measurements. The results obtained implied the high potential of computer-aided simulation tech nique to design moisture-proof packaging of foods.
\end{abstract}

Dried laver, Porphyra yezoensis, is one of the most popular marine products, which is indispensable for Japanese diet. The production had drastically increased to a high level and retained that level so far. This trend has urged the rationalization of distribution techniques and made it important to preserve the products on a long-term basis.

Many studies have indicated that dried laver is very labile for quality deterioration during storage. Stabilities of biliproteins, ${ }^{1) \sim 6)}$ chlorophyll, ${ }^{1)-6)}$ carotenoids $^{1) \sim 9) 6}$ and ascorbic acid

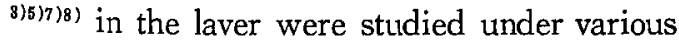
storage conditions. Browning reaction was also investigated as a function of conditions of storage ${ }^{9)}$. Almost all the data presented in those papers suggested that moisture in the laver played a very important role in the deterioration of quality, especially at room temperature. Therefore, the development of a satisfactory method to control the moisture is very important.

A prediction method of moisture change was first introduced to design the packaging for tobacco by OswiN ${ }^{10)}$. HeIss ${ }^{11)}$ also studied the simulation technique to predict moisture increase in crackers. Several workers investigated moisture-proof design aided by computer simulation. ${ }^{12 \sim 16)}$ Hirata et al. ${ }^{17 \sim 19)}$ reported the simulation techniques of moisture change in desiccant-enclosed packaging system at constant and varying temperature.

Recently, a higher percentage of dried laver is further processed and sold as roasted and seasoned ones. It is empirically known that these lavers also require a moisture-proof condition. Therefore, plastic pouch has been used to control the moisture change. For the convenience of the consumer, a large part of these laver is packaged in a portion size and is often double-packaged with water-permeable materials.

The objectives of this work were to specify the hygroscopic properties of the roasted and seasoned lavers on the market, to develop a generalized mathematical model for simulating the moisture change in the packaged products and to determine its feasibility by comparing actual data with calculated results.

\section{Materials and Methods}

\section{Samples}

Roasted and seasoned dried lavers were purchased at the local supermarket.

\section{Packaging materials}

A laminated film of oriented polypropylene and low density polyethylene (OPP/LDPE), and a low density polyethylene (LDPE) film were used. Water permeabilities were 0.053 and $0.117 \mathrm{~g} /$ day $\cdot \mathrm{m}^{2} \cdot \mathrm{mmHg}$, respectively ${ }^{18}$.

Moisture sorption isotherms

Moisture sorption isotherms were determined by equilibrating the samples over saturated salt 
solutions at $25^{\circ} \mathrm{C}$ for 2 days, according to the method previously reported ${ }^{18}$. Moisture content of lavers adjusted to desired water activities was gravimetrically determined by heating for 3 hours at $105^{\circ} \mathrm{C}$.

\section{Preparation for packaging}

About $2 \mathrm{~g}$ of seasoned laver cut into the size of ca. $5 \times 8 \mathrm{~cm}$ was hermetically packaged in a pouch of OPP/LDPE $(5 \times 8 \mathrm{~cm})$. Two of the pouches prepared thus and a LDPE-pouch $(5 \times 8 \mathrm{~cm})$ containing ca. $2 \mathrm{~g}$ of calcium chloride were laid so as not to overlap each other, and packaged with a larger pouch of OPP/LDPE $(10 \times 17 \mathrm{~cm})$. Roasted laver was also cut into small pieces and the pouches containing $2 \mathrm{~g}$ of the laver and desiccant were packaged in the same manner.

\section{Storage test}

The packaged samples were placed in a desiccator in which the relative humidity was adjusted to $75.3 \%$ by saturated sodium chloride. The desiccator was stored in TABAI-PL -3 incubator controlled at $25^{\circ} \mathrm{C}$ and the weight change of each package was determined at previously scheduled intervals.

\section{Computer calculation}

Simulation was done using PC-9800 personal computer (NEC). Curve fitting by means of least squares analysis and numerical analysis of differential equation was performed by BASIC programs ${ }^{18)}$.

Chemicals

All the chemicals were purchased from $\mathrm{Na}$ karai chemicals, Ltd. The water activity of anhydrous calcium chloride measured by $\mathrm{Hy}$ groskop DT (Rotronic, Switzerland) showed zero even after $15 \mathrm{~g}$ of water was absorbed by the $100 \mathrm{~g}$ solid.

\section{Results and Discussion}

Sorption isotherms of roasted and seasoned lavers at $25^{\circ} \mathrm{C}$ are shown in Fig. 1. The water content of roasted laver was rather lower than that of normal dried laver on the same water activity basis. In typical processing lines, roasted laver is prepared by heating at ca. $180-200^{\circ} \mathrm{C}$. and this procedure may cause the change of hygroscopic properties of the laver ${ }^{20}$ ). On the other hand, a higher water content
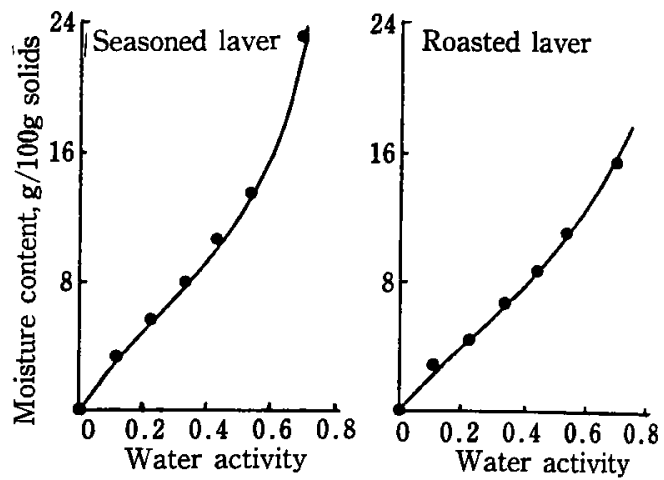

Fig. 1 Sorption isotherms of seasoned and roasted lavers

was observed in seasoned laver than that of dried laver. Hydrophilic seasonings including soy sauce, sugar and so on in the seasoned laver may affect the shape of the isotherms. However, basic sigmoid patterns of the isotherms of both lavers are very similar to that of normal dried laver. Therefore, the empirical equation (1), which was developed to express the isotherms of dried laver ${ }^{17)}$, was successfully applicable for the secondary products.

$$
A w=m^{2} /\left(m^{2}+A m+B\right)
$$

Where $A w$ : Water activity of the laver, $m$ : Moisture content of the laver ( $\mathrm{g} / 100 \mathrm{~g}$ solids), $A, B$ : Constants.

Two parameters $A$ and $B$ were calculated by the least squares analysis, and the final equations obtained were as follows,

$$
\begin{aligned}
& A w=m^{2} /\left(m^{2}+7.71 m+65.36\right) \\
& \text { for seasoned laver } \cdots \cdot \cdot(2) \\
& A w=m^{2} /\left(m^{2}+4.58 m+55.21\right) \\
& \text { for roasted laver } \cdots \cdots \cdot(3)
\end{aligned}
$$

and

Fig. 2 shows a schematic diagram to design a generalized model for simulating the moisture change of dried products in moisture permeable plastic materials. One can assume that hygroscopic samples (water activity: $A w_{1}-A w_{n}$, weight: $W_{1}-W_{n}$, the number: $\left.K_{1}-K_{n}\right)$ are packaged in moisture permeable materials (surface area: $A_{1}-A_{n}$, moisture permeability: $\left.P_{1}-P_{n}\right)$. All the pouches are packaged with a larger 


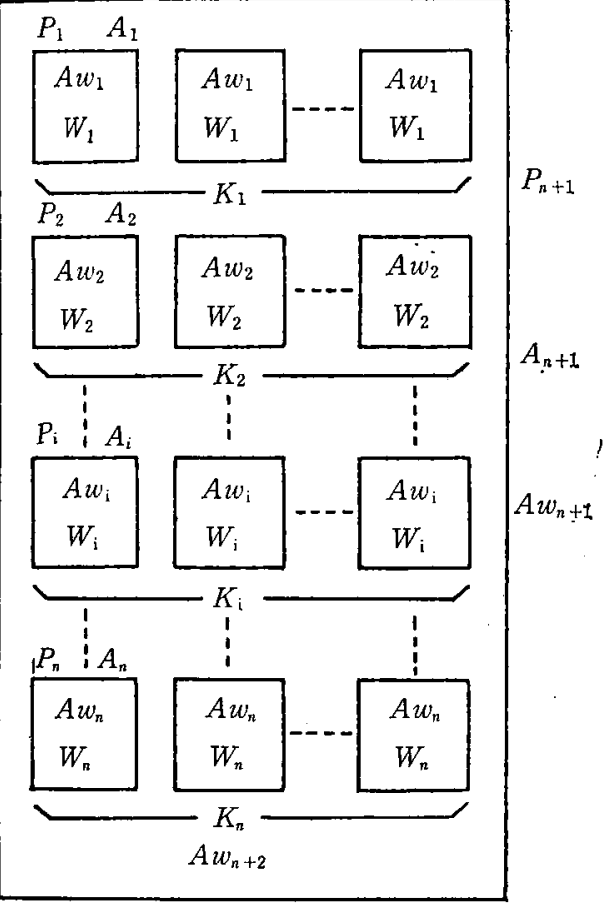

Fig. 2 A schematic diagram of the packaging system

Symbols refer to text.

pouch (surface area: $A_{n+1}$, moisture permeability: $\left.P_{n+1}\right)$.

Transportation rate of moisture across polyolefin film is directly proportional to water vapor difference between both sides of the film ${ }^{17)}$. Therefore, the unsteady state of transportation of moisture into the inside of pouch is given by the differential equation;

$$
d M / d t=p_{25} A_{n+1} P_{n+1}\left(A w_{n+1}-A w_{n+2}\right)
$$

Where $d M / d t$ : Rate of moisture transfer (g/ day), $p_{\mathbf{2 5}}$ : Saturated pressure of water vapor at $25^{\circ} \mathrm{C}(23.756 \mathrm{mmHg}), A_{n+1}$ : Surface area of the outer packaging materials $\left(\mathrm{m}^{2}\right), P_{n+1}$ : Permeability to moisture $\left(\mathrm{g} / \mathrm{day} \cdot \mathrm{m}^{2} \cdot \mathrm{mmHg}\right.$ ), $A w_{n+1}$ : Water activity outside the package, $A w_{n+2}$ : Water activity inside the package.

Since an instantaneous equilibration of moisture in the food can be assumed, the rates of moisture increase of packaged foods are given by;

$$
\begin{aligned}
& d m_{1} / d t=100 p_{25} A_{1} P_{1}\left(A w_{n+2}-A w_{1}\right) / W_{1} \\
& \cdots \cdots(5) \\
& d m_{2} / d t=100 p_{26} A_{2} P_{2}\left(A w_{n+2}-A w_{2}\right) / W_{2} \\
& d m_{i} / d t=100 p_{25} A_{i} P_{i}\left(A w_{n+2}-A w_{i}\right) / W_{i} \\
& d m_{n} / d t=100 p_{25} A_{n} P_{n}\left(\dot{A} w_{n+2}-A w_{n}\right) / W_{n}
\end{aligned}
$$

Where $d m_{1} / d t-d m_{n} / d t$ : Rate of moisture increase of food (g/100g solids.day), $A_{1}-A_{n}$ : Surface area of inner pouch $\left(\mathrm{m}^{2}\right), A w_{1}-A w_{n}$ : Water activity of sample, $P_{1}-P_{n}$ : Moisture permeability of inner pouch $\left(\mathrm{g} /\right.$ day $\left.\cdot \mathrm{m}^{2} \cdot \mathrm{mmHg}\right)$, $W_{1}-W_{n}$ : Weight of solids in sample (g).

If permeation rate of moisture across the inner small pouches is sufficiently high, it can be considered that the amount of moisture which penetrates into the larger pouch from outside is equivalent to the amount of moisture absorbed by food sample in individual small pouches. Therefore, the following relationship can be obtained,

$$
\begin{array}{r}
\frac{d M}{d t}=\frac{1}{100}\left(K_{1} W_{1} \frac{d m_{1}}{d t}+K_{\mathrm{2}} W_{\mathrm{2}} \frac{d m_{\mathrm{2}}}{d t}+\cdots\right. \\
\left.+K_{i} W_{i} \frac{d m_{i}}{d t}+\cdots+K_{n} W_{n} \frac{d m_{n}}{d t}\right)
\end{array}
$$

By substituting equations (4) and (5)-(8) into equation (9), we obtain,

$$
A w_{n+2}=\frac{\sum_{j=1}^{n+1} K_{j} A_{j} P_{j} A w_{j}}{\sum_{j=1}^{n+1} K_{j} A_{j} P_{j}} \cdots \cdots \ldots \ldots \ldots \ldots(10)
$$

Where $K_{n+1}=1$ : the number of outer large pouch.

Rearrangement of equation (7) by substituting equation (10) into yields,

$$
\begin{array}{r}
\frac{d m_{i}}{d t}=\frac{100 p_{25} A_{i} P_{i}}{W_{i} \sum_{j=1}^{n+1} K_{j} A_{j} P_{j}} \sum_{j=1}^{n+1} K_{j} A_{j} P_{j}\left(A w_{j}-A w_{i}\right) \\
(i=1,2,3, \cdots \cdots \cdot(11)
\end{array}
$$

Equation (11) is the generalized model for sim- 
ulating moisture change of food packaged by the double-packaging system. If equation (11) is rearranged with $\mathrm{n}=1$ and $P_{2}-\infty$, The following equation may be obtained,

$$
d m / d t=100 p_{25} A_{1} P_{1}\left(A w_{2}-A w_{1}\right) / W_{1}
$$

If one considers $A w_{2}$ is the water activity outside a pouch, equation (12) express the simplest packahing system which contains food samples without outer materials.

For the packaging test of roasted and seasoned lavers, the schematic diagram of the packaging system shown in Fig. 1 must be converted to the appropriate double-packaging system with $n=2, \quad K_{1}=1, \quad K_{2}=2$ and $K_{3}=1$. The mathematical models, equation (13) and equation (14), expressing the double-packaging system of seasoned laver is obtained from equation (11).

$$
\begin{aligned}
d m_{1} / d t= & \frac{100 p_{25} A_{1} P_{1}}{W_{1}\left(A_{1} P_{1}+2 A_{2} P_{2}+A_{8} P_{3}\right)} \times \\
& \left(2 A_{2} P_{2} A w_{2}+A_{8} P_{8} A w_{3}\right) \\
d m_{2} / d t= & \frac{100 p_{25} A_{2} P_{2}}{W_{2}\left(A_{1} P_{1}+2 A_{2} P_{2}+A_{8} P_{3}\right)} \times(13) \\
& \left(A_{8} P_{3}\left(A w_{3}-A w_{2}\right)-A_{1} P_{1} A w_{3}\right)
\end{aligned}
$$

Where $d m_{1} / d t$ : Rate of moisture increase of desiccant ( $\mathrm{g} / 100 \mathrm{~g}$ solids $\cdot$ day), $d m_{2} / d t$ : Rate of moisture increase of seasoned laver $(\mathrm{g} / 100 \mathrm{~g}$ solids.day), $P_{1}-P_{\mathrm{a}}$ : Moisture permeability (g/ day $\mathrm{m}^{2} \cdot \mathrm{mmHg}$ ) of the pouches of desiccant, seasoned laver and outer materials, $A_{1}-A_{3}$ : Surface area of each pouch $\left(\mathrm{m}^{2}\right), A w_{2}$ : Water activity of seasoned laver, $A w_{s}$ : Relative humidity of storage atmosphere divided by 100 .

Fig. 3 indicates that simulated and actual changes of moisture content in the seasoned as well as in the roasted laver and desiccant. Fairly good agreements which are adequate to practical purposes, are obtained between predicted and actual values.

Thus the generalized mathematical model presented is the one that helps to optimize the design of moisture-proof package. It must be also noted that all the equations previously reported ${ }^{17 \sim 19)}$ for predicting the shelf-life can be introduced from the model by substituting real numbers for the signs. It has not been demonstrated, however, that the model could be feasible to packaging systems of hydrophilic packaging materials of which permeability to moisture are humidity-dependent. This will be the subject of a future work.

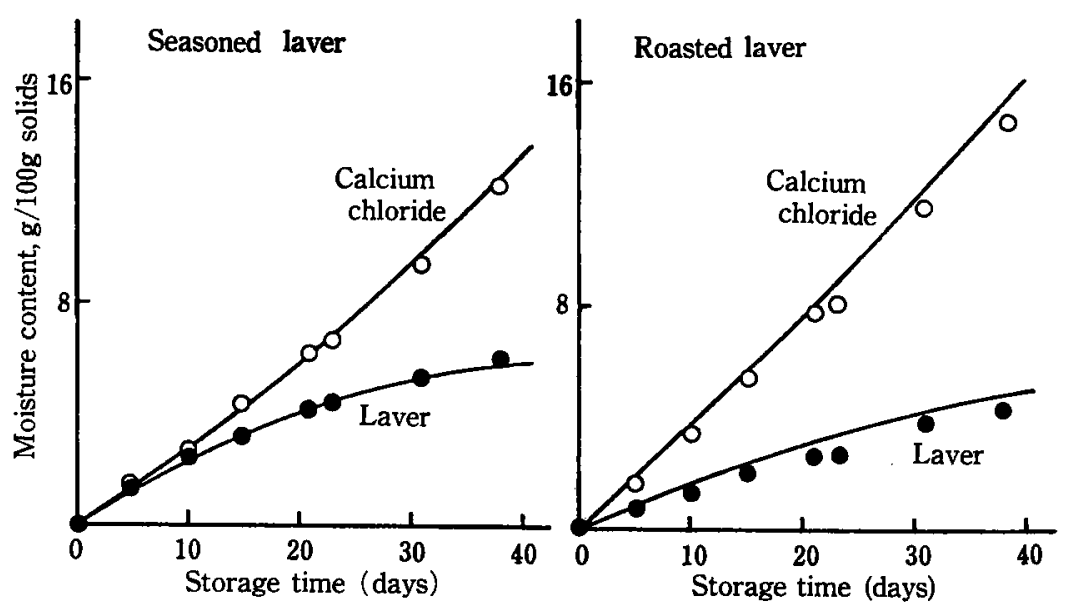

Fig. 3 Predicted and actual changes of moisture content in laver and calcium chloride during storage at $25^{\circ} \mathrm{C}$

- Predicted value, 0 - Actual value 


\section{References}

1) TsuchiYa, Y., SuzUKI, Y. and SASAKI, T. : Bull. Japan. Soc. Sci. Fish., 27, 919 (1961).

2) Park, Y-H., Kolzumi, $\mathrm{C}$ and Nonaka, J. : Bull. Japan. Soc. Sci. Fish., 39, 1045 (1973).

3) Yamashita, T.: Bulletin of Hiroshima Food Research Institute, 14, 41 (1977).

4) Hirata, T., Ishitani, $T$. and Yamada, T. : Bull. Japan. Soc. Sci. Fish., 47, 89 (1981).

5) Hirata, T., Tanaka, Y. and Ishitani, T. : Nippon Shokuhin Kogyo Gakkaishi, 31, 272 (1984).

6) Araki, S., Ogawa, H., Oohusa, T., Ueno, J., SaIto, M., Imayoshi, J. and Kayama, M. : Bull. Japan. Soc. Sci. Fish., 48, 647 (1982).

7) Araki, S., Ogawa, H., Oohusa, T., Saito, M., Ueno, J. and Kayama, M. : Bull. Japan. Soc. Sci. Fish., 48, 643 (1982).

8) Ogawa, H., Araki, S., Oohusa, T. and Kayama, M. : Bull. Japan. Soc. Sci. Fish., 49, 1143 (1983).

9) Ogawa, H., Araki, S., Oohusa, T. and Kayama, M.: Bull. Japan. Soc. Sci. Fish., 51, 433 (1985).

10) Oswin, C. R. : J. Soc. Chem. Ind., 64, 67 (1945).

11) Heiss, R. : Modern Packaging, 31, 119 (1958).

12) Mizrahi, S., Labuza, T.P. and Karel, M. : J. Food Sci., 35, 799 (1970).

13) Mizrahi, S., Labuza, T.P. and Karel, M. : J. Food Sci., 35, 804 (1970).

14) Simon, I. B., LabuzA, T. P. and Karel, M. : J. Food Sci., 36, 280 (1971).

15) Quast, D. G. and Karel, M. : J. Food Sci., 37, 679 (1972).

16) Purwadaria, H. K., Heldman, D. R. and Kirk,
J. R. : J. Food Proc. Eng., 3, 7 (1979).

17) Hirata, T., Tanaka, $Y$. and Ishitani, $T_{.}$: Bull. Japan. Soc. Sci. Fish.. 50, 899 (1984).

18) Hirata, T. and Ishitani, T.: Nippon Shokuhin Kogyo Gakkaishi. 32, 266 (1985).

19) Hirata, T., JHEIKH, A. and Ishitani, T. : Nippon Shokuhin Kogyo Gakkaishi. 32, 426 (1985).

20) Araki, S., Ma, J., Ogawa, H., Oohusa, T. and Kayama, M: Bull. Japan. Soc. Sci. Fish. 51, 1109 (1985).

(Received Jan. 24, 1986)

\section{二重包装した焼きのりと 味付けのりの水分変化の予測}

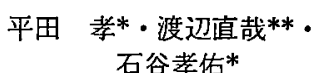

*農林水産省食品総合研究所

(T 305 茨城県筑波郡谷田部町観音台 2-1-2)

**クノール食品枺式会社

（广 213 神奈川県川猗市高津区下野毛 976）

二重包装した焼きのりと味付けのりの水分変化を予測 する手法について検討した．まず，燃きのり，味付けの りの水分収着等温線を作成し, 経験式に当てはめた。 各 種の包装形態に適用できるように一般化した数学モデル と水分収着等温線の経験式を用いて，二重包装した焼き のり，味付けのりの水分変化をシミュレートした. 開発 した数学モデルによって計算された予測值恃実測值と良 く一致した. コンピューターシミュレーションは乾燥食 品の防湿包装設計に有益であると考えられた。 